Article

\title{
Potential Biogas Production from Artichoke Byproducts in Sardinia, Italy
}

\author{
Fabio De Menna ${ }^{1, *}$, Remo Alessio Malagnino ${ }^{1}$, Matteo Vittuari ${ }^{1}$, Giovanni Molari ${ }^{1}$, \\ Giovanna Seddaiu ${ }^{2,3}$, Paola A. Deligios ${ }^{2}$, Stefania Solinas ${ }^{3}$ and Luigi Ledda ${ }^{2,3}$ \\ 1 Department of Agricultural and Food Sciences, University of Bologna, Viale Giuseppe Fanin 50, \\ Bologna 40127, Italy; remo.malagnino2@unibo.it (R.A.M.); matteo.vittuari@unibo.it (M.V.); \\ giovanni.molari@unibo.it (G.M.) \\ 2 Department of Agricultural Sciences, University of Sassari, Viale Italia 39, Sassari 07100, Italy; \\ gseddaiu@uniss.it (G.S.); pdeli@uniss.it (P.A.D.); lledda@uniss.it (L.L.) \\ 3 Desertification Research Centre-NRD, University of Sassari, Viale Italia 39, Sassari 07100, Italy; \\ ssolinas@uniss.it \\ * Correspondence: fabio.demenna2@unibo.it; Tel.: +39-051-209-6150
}

Academic Editor: Thomas E. Amidon

Received: 6 November 2015; Accepted: 26 January 2016; Published: 2 February 2016

\begin{abstract}
The paper aims at evaluating the potential biogas production, both in terms of $\mathrm{CH}_{4}$ and theoretical energy potential, from globe artichoke agricultural byproducts in Sardinia. Field data about the productivity of byproducts were collected on five artichoke varieties cultivated in Sardinia, to assess the biomethane production of their aboveground non-food parts (excluding the head). Moreover, secondary data from previous studies and surveys at regional scale were collected to evaluate the potential biogas production of the different districts. Fresh globe artichoke residues yielded, on average, $292.2 \mathrm{Nm}^{3} \cdot \mathrm{t}_{\mathrm{DOM}}{ }^{-1}$, with dissimilarities among cultivars. Fresh samples were analyzed in two series: (a) wet basis; and (b) wet basis with catalytic enzymes application. Enzymes proved to have some beneficial effects in terms of anticipated biomethane availability. At'the regional level, ab. $20 \times 10^{6} \mathrm{Nm}^{3} \mathrm{CH}_{4}$ could be produced, corresponding to the $60 \%$ of current installed capacity. However, districts potentials show some differences, depending on the specific biomass partitioning and on the productivity of cultivated varieties. Regional assessments should encompass the sensitiveness of results to agro-economic variables and the economic impacts of globe artichoke residue use in the current regional biogas sector.
\end{abstract}

Keywords: artichoke; byproducts; biogas; Sardinia

\section{Introduction}

In the last decade, Europe witnessed a fast-paced growth of the biogas sector, which rapidly became the fourth renewable energy source, contributing with more than $52 \times 10^{12}$ Wh of electricity produced in 2013. Germany and Italy are regional leaders, especially in the agricultural biogas subsector [1]. European and, more importantly, national legislative frameworks proved crucial in fostering this growth and its features [2]. In Italy the introduction of a large feed-in tariff in 2009 led to an rapid increase in the number of plants [3] with a homogenization of size, technologies, and feedstock towards $1 \mathrm{MW}$ plants fed with energy crops and manure [3,4].

However, this specific pattern provoked several criticisms and problems. In fact, the use of dedicated crops for first generation biofuel has been accruing the competition for resources between food, feed, and fuel [5-9]. This also happened in the case of biogas from energy crops. For example, German production has been reputed to have a significant consequence in terms of European and global prices and land use change [2]. Additionally, at the farm level, the need to substitute maize directed towards energy 
production led to increased consumption of concentrated feed or to marginal land use change [10]. Furthermore, anaerobic digestion (AD) of energy crops usually present negative environmental impacts, deriving from the use of fossil fuel and chemical fertilizer during their cultivation [11-13].

The Italian government extensively revised its renewable energy policy, lowering feed-in tariffs for electricity generated from biogas. In particular, higher incentives are now assigned only to plants with a small size (0-300 kW) and fed with residual feedstock, such as agro-industrial byproducts [14]. The use of these biomasses is in fact reputed to decrease the biogas-related land use $[15,16]$, its competition with food and feed [10], as well as associated environmental impacts [11] and feeding costs [17]. It delivers improved waste management [18] and a potential source of energy for agro-food systems, reducing their fossil fuel dependence [19]. Furthermore, the use of local residual biomasses allows the creation of new value chains from neglected territorial resources or income diversification possibilities for existing agro-industrial economies [4,20-22]. For this reason, various studies verified the promising potential of residues from tomato [23], potato [24], beet pulp [25], and citrus [26].

Globe artichoke (Cynara cardunculus L. var. scolymus) is a variety of thistle diffusely-cultivated as food, especially in Mediterranean countries. Italy represents the main producer, covering almost one third of the global market with ca. 540,000 t produced [27], and Sardinia is one of the leading regions, with ca. 11,000 ha in 2015 [28]. Artichoke cultivation is aimed at the harvest of the large and fleshy flower buds. Thus, the farming segment is characterized by a large share of residuals, comprised between $80 \%$ and $85 \%$ of the aboveground biomass, depending on cultivars, final use of edible parts, and agricultural practices [29,30]. Most of this aboveground biomass is either burned or buried, as it is not considered valuable.

Globe artichoke is a promising double-purpose crop, as residues from its supply chain could represent an interesting feedstock for bioenergy and biorefineries [31-35]. Furthermore, the Sardinia region included artichoke among the regional biomass supply chains for anaerobic digestion [36]. However, only little research aimed at verifying the biomethane potential (BMP) of artichoke residues, mainly from the processing phase. An early study analyzed processing wastes from a food industry treating artichokes [37], in co-digestion with cattle manure. More recently, Ros et al. [38] evaluated the effects on BMP of the insertion of fresh artichoke waste in the AD of fruit and vegetable processing sludge. Another study aimed at assessing the high solids AD, using artichoke industrial waste in co-digestion with other feedstock and sewage sludge [39]. Fabbri et al. [40] verified the anaerobic digestibility of artichoke processing waste through a series of batch tests with different inoculum/substrate ratios. Finally, a recent research by Scano et al. [41] evaluated the potential performance of a full-scale power plant fed with various fruit and vegetable wastes from a wholesale market, including artichoke byproducts.

So far no study specifically analyzed the BMP from artichoke crop residues. Only Oliveira et al. [42] analyzed the chemical composition and the biogas potential of Cynara cardunculus L. stalks, without indicating the variety. Therefore, the main purpose of this study was the evaluation of the biogas potential of different cultivars of globe artichoke and the estimate of the related energy potential in the Sardinia region.

\section{Materials and Methods}

\subsection{Field Trial}

A field trial was carried out at the experimental farm of the University of Sassari to evaluate the residual biomass potential of five varieties of globe artichoke. The experiment was located in Ottava (Sassari, Italy) ( $40^{\circ} 43^{\prime} \mathrm{N}, 80 \mathrm{~m}$ a.s.l.), during the 2013/2014 and 2014/2015 growing seasons. The climate is Mediterranean with mild winters, yearly average precipitation is around $554 \mathrm{~mm}$, and annual average temperature is $17^{\circ} \mathrm{C}$. The soil is sandy-clay-loam overlaid on limestone (Xerochrepts), with an average $\mathrm{N}$ content of $0.76 \%$, and a $\mathrm{C} / \mathrm{N}$ ratio of 12 . The soil organic carbon (SOC) content was 1.97 and 1.69 for the $0-30 \mathrm{~cm}$ and the $30-60 \mathrm{~cm}$ soil layers, respectively. Soil pH was 8.3 . The soil water contents at field capacity and wilting point were $22.4 \%$ and $11.9 \%$ (on a dry weight basis), respectively. 


\subsection{Plant Material and Crop Management}

Planting date was anticipated at the end of July, to reflect the usual practice in Sardinia, where globe artichokes are planted earlier so to compete in the early winter fresh market. The five cultivars studied (C3, Madrigal, Spinoso sardo, Tema, and Violetto) comprised the most widely grown and the highest-performing recent releases (e.g., Madrigal). Each plot consisted of four $28 \mathrm{~m}$ long rows, and was set out as randomized complete block design with four replicated blocks. The globe artichoke plants were grown at a distance of $1.4 \mathrm{~m}$ between and along the rows ( 8000 plants ha $\left.{ }^{-1}\right)$. As for common agronomic practices, fertilizer, and irrigation were applied to prevent any nutritional or water stress. Weeds, pests, and diseases were chemically controlled according to the conventional practice.

\subsection{Data Collection and Analysis}

Heads were collected monthly to detect fresh production for each variety and block. Every year, at the end of harvest for the fresh market, 20 plants (one plant per variety per block) were collected from the middle of the two central rows to avoid edge effects. Harvested plants were weighed in the field to determine fresh residual biomass yield. Fresh samples of each plant were coarsely ground in a Stihl Viking GE250 (Milan, Italy) mill, and homogenized to a particles size of $5 \mathrm{~cm}$. After milling, they were stored under vacuum until analysis. All results were expressed as means and standard deviations of four replicates. Data for heads and byproducts yields were subjected to analysis of variance (ANOVA) using the GLM procedure of SAS statistical software (v. 9.3 SAS Institute, Cary, NC, USA). Mean comparisons were carried out with a Tukey HSD (Honestly Significant Difference") post hoc test [43].

\subsection{Biomethane Potential Testing}

One fresh sample for each of the five cultivars was collected for BMP testing after the end of harvest in the year 2014/2015. An early chemical characterization was carried out to assess dry matter (DM) and organic dry matter (DOM) content on wet basis. BMP testing was performed under two test conditions: (A) wet basis; and (B) wet basis with application of catalytic enzymes. This pretreatment is commonly adopted to improve the biodegradability of lignocellulosic feedstocks [44], where the hemicellulose and cellulose contents are higher than 30\% (in dry weight basis), such as in globe artichoke [45]. As other biological pretreatment, it does not require the installation of further equipment on existing plants. Furthermore, it allows reducing electricity self-consumption, thanks to an improvement of the fluidity during the mixing process [46]. The non-GMO enzyme preparation used contained cellulase, xylanase, beta-glucanase, and other carbohydrase activities originating from a selected strain of Trichoderma reesei [47].

Biomethane potential trials were performed in batch reactors with a 31-days test time, under mesophilic condition $\left(39^{\circ} \mathrm{C}\right)$. For each sample, the optimal substrate/inoculum ratio was defined according to the VDI 4630 standard [48]. Every sample was investigated in triplicate and homogenized in order to ensure comparable results in every experiment. The AD was carried out in $0.5 \mathrm{~L}$ vessels, mixing the content on a daily basis, to guarantee the steady degradation of the organic substances.

Biogas production was measured on a volumetric basis using an eudiometer [49]. The measured gas volume was then converted to dry conditions to allow the comparability with literature values. At every volume measurement, methane content was measured using gas chromatography. The biogas analyzer was characterized by a sensitivity of $\pm 1 \%$ for content percentages between $0.25 \%-80.00 \% v / v$.

Finally, a statistical analysis was performed using ANOVA followed by a Tukey HSD post hoc test for both conditions (A and B) [43].

\subsection{Geo-Database Development at the Regional Scale}

Data on the regional production were obtained by elaborating information provided by previous studies carried out at district level, as reported in Table 1. Experimental data on agronomic features (heads and byproduct yields) of the five cultivars (Table 2) were confirmed by in-depth 
interviews to representatives of regional sectorial agencies for rural and agricultural development and regional agricultural research institutions [50-52]. Based on Raccuia et al. [30], possible differences in biomass composition deriving from site-specific conditions were considered as negligible in respect to differences related to genotypes characteristics.

Table 1. Sardinian artichoke districts, year 2015. Authors' elaboration on data from [36,50-52].

\begin{tabular}{cccccccc}
\hline \multirow{2}{*}{ District } & \multirow{2}{*}{$\begin{array}{c}\text { Denomination } \\
\text { (n of Municipalities) }\end{array}$} & \multirow{2}{*}{ Area (ha) } & \multicolumn{5}{c}{ Cultivar Distribution (\%) } \\
\cline { 4 - 7 } & & & Spinoso & Tema & Madrigal & C3 & Violetto \\
\hline D1 & Coros-Nurra (8) & 2250 & 100 & - & - & - & - \\
D2 & Valle del Coghinas-Anglona (3) & 3451 & 95 & 5 & - & - & - \\
D3 & Oristano (6) & 1050 & 80 & 10 & 10 & - & - \\
D4 & Medio Campidano-Cagliari (4) & 3000 & 60 & - & 5 & 15 & 20 \\
D5 & Sulcis (3) & 1000 & 100 & - & - & - & - \\
& Sardinia Region & 10,751 & 85 & 3 & 2 & 4 & 6 \\
\hline
\end{tabular}

The theoretical biomethane potential at the regional level was assessed with reference to 2015, based on: agronomic byproduct yield measured over the two-year period and confirmed by expert interviews; BMP test results of the sample collected in 2015; and district characterization (Table 1). Estimated ranges of biomethane yield per ha of the $i$-esime cultivar byproducts $\left(\mathrm{BMC}_{\mathrm{i}}\right)$ were calculated basing on BMP results and the amount of residues. Then, $\mathrm{BMC}_{\mathrm{i}}$ was combined with the amount of ha cultivated per each cultivar and district. It must be noted that, given their seasonal availability, the use of artichoke byproducts in real-scale biogas plants would be in co-digestion with other feedstocks. Thus, territorial extrapolations should be carefully regarded as theoretical estimates. Nonetheless, energy considerations on a regional scale are particularly useful, especially from a policy-maker perspective [3]. Therefore, ranges of estimated biomethane potentials per district $\left(\mathrm{BMM}_{\mathrm{j}}\right)$ were calculated and geo-referenced on the administrative (Local Administrative Unit-LAU2) scale of Sardinia, using Q-GIS®(Pisa v. 2.0). The resulting multi-layered map contains information on both the quantitative theoretical potential per district and the contribution of cultivars, in order to identify the most promising districts.

\section{Results and Discussion}

\subsection{Difference between Cultivars}

The best performing cultivar in terms of byproducts yield (Table 2) was Madrigal. This is a vigorous late hybrid characterized by a long growing cycle and a short heads harvest period (from April to May). The most common cultivar in Sardinia, Spinoso sardo, showed a statistically significant low byproduct yield, since it is characterized by an early and long harvest period (from November to March) and, as a consequence, by an early senescence phase. Violetto showed an overlapping cycle to Spinoso sardo, but a statistically significant lower byproduct yield.

Furthermore, these figures can be considered in line with previous generic estimates referred to Sardinia. In fact, if results from Table 2 are weighed on the regional cultivar composition (Table 1) it is possible to derive an average byproduct yield equal to $40.1 \mathrm{t} \cdot \mathrm{ha}^{-1}$, which is slightly above the $35 \mathrm{t} \cdot \mathrm{ha}^{-1}$ reported by Scano et al. [36], without detailing the varieties.

Table 2. Agronomic features of the five cultivars (heads and byproduct yields are mean values \pm standard deviation of four replicates). Means in columns followed by different letters differ $(p<0.05)$.

\begin{tabular}{ccccc}
\hline Cultivar & $\begin{array}{c}\text { Heads: Yield } \\
\left(\mathbf{t} \cdot \mathbf{h a}^{-1} \mathbf{)}\right.\end{array}$ & $\begin{array}{c}\text { Byproduct: } \\
\text { Yield }\left(\mathbf{t} \cdot \mathbf{h a}^{-1} \mathbf{)}\right.\end{array}$ & $\begin{array}{c}\text { Byproduct: DM } \\
\mathbf{( \% )}\end{array}$ & $\begin{array}{c}\text { Byproduct: } \\
\text { DOM (\%) }\end{array}$ \\
\hline Madrigal & $30.5 \pm 0.06 \mathrm{a}$ & $143.4 \pm 0.23 \mathrm{a}$ & 20.7 & 87.9 \\
Spinoso sardo & $4.2 \pm 0.02 \mathrm{~b}$ & $37.0 \pm 0.31 \mathrm{~b}$ & 17.3 & 84.5 \\
C3 & $4.3 \pm 0.13 \mathrm{~b}$ & $50.0 \pm 0.03 \mathrm{c}$ & 22.5 & 87.1 \\
Tema & $12.5 \pm 0.07 \mathrm{c}$ & $75.5 \pm 0.87 \mathrm{~d}$ & 21.1 & 89.7 \\
Violetto & $3.2 \pm 0.02 \mathrm{~b}$ & $25.2 \pm 0.24 \mathrm{e}$ & 22.1 & 88.1 \\
\hline
\end{tabular}


The average DM content of the five varieties was largely below the $40 \%$, which is commonly suggested as threshold value for AD feeding [53]. Moreover, DOM percentages approaching $90 \%$ anticipate the suitability of artichoke for biogas production [54]. In fact, based on results shown in Table 3, the BMP value (test condition A) is on average equal to $292.2 \mathrm{Nm}^{3} \cdot \mathrm{t}_{\mathrm{DOM}}{ }^{-1}$, which is $c a .21 \%$ lower than figures referred to fiber corn [55] and 25\% lower than averages referred to maize silage [56]. However, artichoke residues should be compared with other regionally available byproducts. For example, they have a theoretical BMP per $t_{\mathrm{DOM}}$ that is $34 \%$ higher than tomato skins and seeds, and similar to wasted tomatoes $[23,53]$.

These results are also in line with Fabbri et al. [40], which assessed the anaerobic digestibility of processing waste, through a series of 40-day batch tests with different inoculum/substrate ratios. Their results suggest how cumulative biomethane production reaches almost a steady state after the 31 st day, with a BMP mean value of $325.0 \pm 65.6 \mathrm{Nm}^{3} \cdot \mathrm{t}_{\mathrm{DOM}}{ }^{-1}$. This figure is slightly higher than results reported in Table 3, likely due to a larger share of DOM in their substrate. In fact, being fresh artichoke industrial waste, samples were composed of leaves and external bracts of heads, rather than leaves and stalks. It is not possible to consistently compare the results of this study with other research, as most of them focused on the co-digestion of processing byproducts with other feedstocks [37-39], while Oliveira et al. [42] analyzed the biogas potential of stalks, without specifying the variety.

Table 3. BMP testing report ( $\mathrm{A}=$ wet basis; $\mathrm{B}=$ wet basis with catalytic enzymes). Means in columns followed by different letters differ $(p<0.05)$.

\begin{tabular}{ccc}
\hline Cultivar & \multicolumn{2}{c}{$\mathbf{B M P}\left(\mathbf{N m}^{3} \cdot \mathbf{t}_{\mathbf{D O M}}{ }^{-1}\right)$} \\
\hline A & B \\
Madrigal & $293.9 \pm 1.3 \mathrm{a}$ & $292.9 \pm 14.5 \mathrm{a}, \mathrm{b}$ \\
Spinoso sardo & $298.9 \pm 5.1 \mathrm{a}$ & $310.5 \pm 9.5 \mathrm{~b}$ \\
C3 & $303.9 \pm 2.0 \mathrm{a}$ & $300.3 \pm 9.0 \mathrm{a}, \mathrm{b}$ \\
Tema & $304.0 \pm 14.6 \mathrm{a}$ & $306.9 \pm 7.1 \mathrm{a}, \mathrm{b}$ \\
Violetto & $259.9 \pm 5.1 \mathrm{~b}$ & $265.2 \pm 22.1 \mathrm{a}$ \\
\hline
\end{tabular}

When comparing BMP results of the different cultivars (test condition A), it is possible to identify some basic features. First of all, C3 and Tema cultivars showed the highest value $\left(304.0 \mathrm{Nm}^{3} \cdot \mathrm{t}_{\mathrm{DOM}}{ }^{-1}\right)$ but this difference was not statistically significant in comparison with Madrigal and Spinoso. Violetto had a significantly lower performance $\left(259.9 \mathrm{Nm}^{3} \cdot \mathrm{t}_{\mathrm{DOM}}{ }^{-1}\right)$ than other cultivars. However, results are slightly different when BMP is referred to wet weight, as Spinoso is able to produce only $43.7 \mathrm{Nm}^{3} \cdot \mathrm{t}^{-1}$ due to its lower DOM content. For the same reason, $\mathrm{C} 3$ seems to be the most promising cultivar also on a wet weight basis, reaching $59.6 \mathrm{Nm}^{3} \cdot \mathrm{t}^{-1}$.

As for test conditions $B$, on average it was not possible to observe a significant positive effect on BMP $\left(295.2 \mathrm{Nm}^{3} \cdot \mathrm{t}_{\mathrm{DOM}}{ }^{-1}\right)$. When compared to results under test conditions $\mathrm{A}$, there is $\mathrm{a}+1.1 \%$ increase in terms of the biomethane yield. In other words, this confirms that catalytic enzymes could be used to reach only a marginal saving in terms of feedstock consumption [46].

However, some differences could be detected among the five cultivars. Spinoso sardo, Violetto, and Tema showed a positive effect of enzymes on BMP $(+4.0 \%,+1.9 \%$, and $+1.0 \%$ respectively), while Madrigal and, especially, C3 were negatively affected $(-0.3 \%$ and $-1.3 \%)$. This could be related to the higher lignin content of byproducts of the latest two cultivars [44]. It must be noted how enzymes generally increased the variability of BMP values for all cultivars with the exception of Tema, and reduced the distance between Violetto and other cultivars, except for Spinoso sardo.

This aspect could be also highlighted by the differences between cumulative trends under test conditions A and B. In fact, as shown in Figure 1, under test conditions B, BMP rates appeared to be enhanced mostly during the early days while, afterwards, trends start to follow similar patterns. In other words, catalytic enzymes addition could allow anticipating the biomethane availability in comparison with test conditions A. This confirms the potential application of this pretreatment in the co-digestion of artichoke residues with slowly biodegradable biomasses, such as livestock waste [44,53]. 

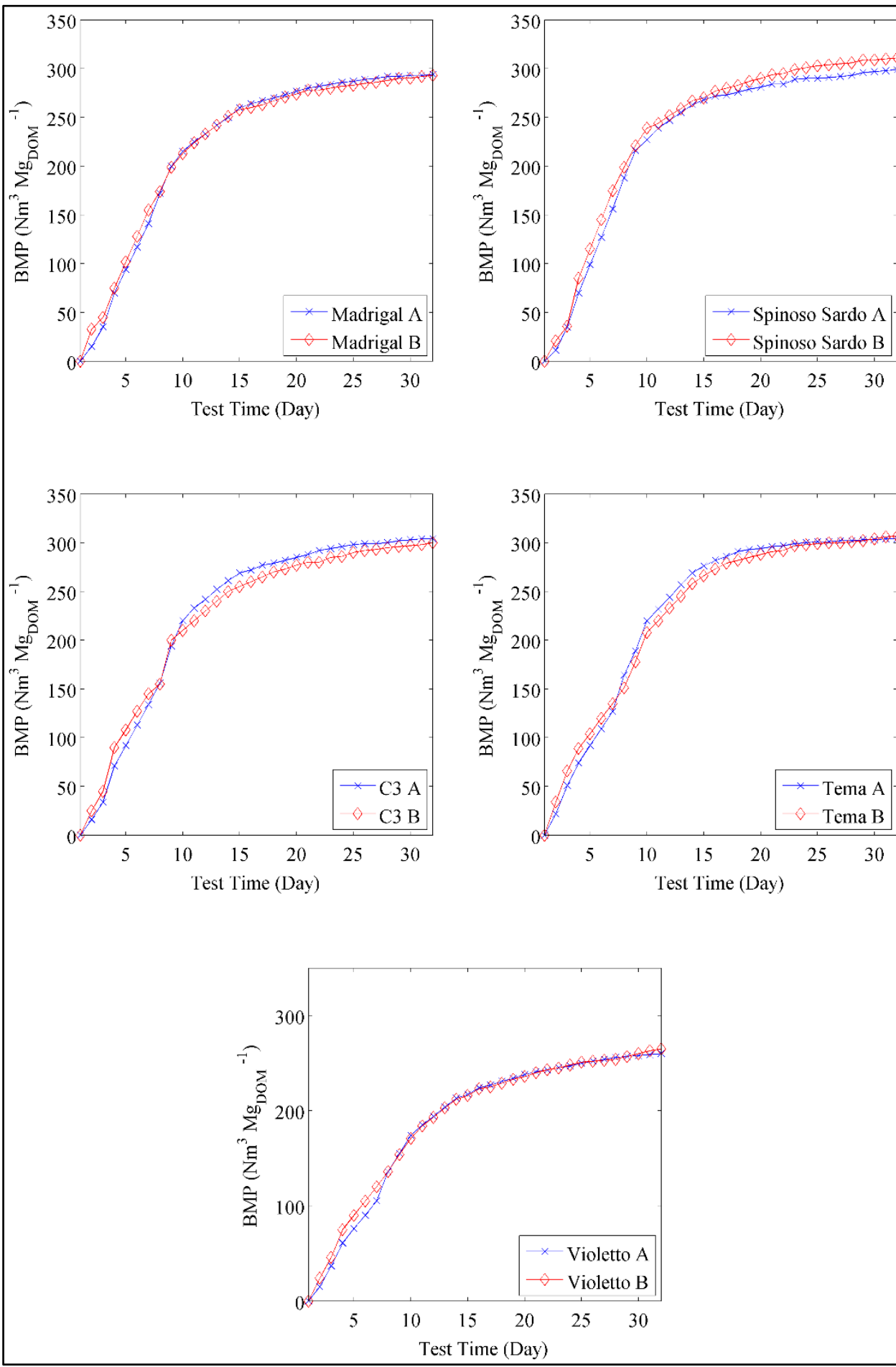

Figure 1. BMP cumulative trends.

As shown in Table 4, with respect to $\mathrm{BMC}_{\mathrm{i}}$, differences between cultivars reflect the amount of byproducts per ha. Results are presented in separate columns because, as mentioned, there is a different effect of enzymes among varieties (Table 3), which is relevant for AD plant owners that plan the co-digestion of artichoke byproducts with or without this pretreatment. Thus, Madrigal represents, by far, the most promising variety of globe artichoke, generally because of the high quantity of residual biomass. On the other hand, Violetto seems less favorable, due to its low performance both in terms of residual mass and BMP. Nonetheless, these figures should be carefully regarded as 
a preliminary assessment, due to the potential regional variability of actual climatic and agronomic conditions. Furthermore, it must be highlighted how these varieties also have quite different head yields, harvest periods, marketability, and final use. Therefore, the potentiality of the specific cultivar as a double purpose crop could also be not sufficient to influence farmers cropping decisions (see Tables 1 and 2). Bioenergy potential differences could in the future have some influence on these choices: for example farmers owning biogas plants or nearby artichoke producers could decide to crop Madrigal or Tema, not only for their food production but also for their energy potential.

Table 4. Biomethane yield ranges per ha $\left(\mathrm{BMC}_{\mathrm{i}}\right)(\mathrm{A}=$ wet basis; $\mathrm{B}=$ wet basis with catalytic enzymes).

\begin{tabular}{ccc}
\hline Cultivar & \multicolumn{2}{c}{$B \boldsymbol{M C} \boldsymbol{C}_{\boldsymbol{i}}\left(\mathbf{N m}^{\mathbf{3}} \mathbf{h a}^{-1}\right)$} \\
\hline & $\mathrm{A}$ & $\mathrm{B}$ \\
Madrigal & $7622.3-7714.7$ & $7252.4-8033.6$ \\
Spinoso sardo & $1575.8-1658.1$ & $1614.4-1745.3$ \\
C3 & $2956.5-2999.2$ & $2852.7-3032.6$ \\
Tema & $4087.8-4605.1$ & $4234.7-4538.7$ \\
Violetto & $1238.3-1312.6$ & $1181.4-1423.1$ \\
\hline
\end{tabular}

\subsection{Regional Assessment}

The theoretical biomethane potential from artichoke residues in the different districts is reported in Table 5, while Figure 2 geographically represents the districts with the respective cultivar contributions on biomethane potential. At the regional level, $c a .20 \times 10^{6} \mathrm{Nm}^{3} \mathrm{CH}_{4}$ could be produced, corresponding to $60 \%$ of current installed capacity, roughly 10 biogas plants with $1 \mathrm{MW}$ of nominal power. D2 and D4, which have the largest amount of land under cultivation, could naturally be also important areas of feedstock supply for biogas plants. Combined, they might represent the $60 \%$ of the total regional potential, while another $18 \%$ could be sourced from D1. The current 1050 ha cultivated in D3 could then provide $c a$. $2.6 \times 10^{6} \mathrm{Nm}^{3}$, while D5 would produce only $1.6 \times 10^{6} \mathrm{Nm}^{3}$, which is $c a .8 \%$ of the total.

Table 5. Biomethane potential ranges per each district, year 2015.

\begin{tabular}{cc}
\hline Districts & Biomethane $\left(\mathbf{1 0}^{\mathbf{6}} \mathbf{N m}^{\mathbf{3}}\right)$ \\
\hline D1 & $3.5-3.9$ \\
D2 & $5.9-6.5$ \\
D3 & $2.6-2.8$ \\
D4 & $6.0-6.6$ \\
D5 & $1.6-1.7$ \\
Sardinia Region & $19.6-21.5$ \\
\hline
\end{tabular}

However, districts are characterized by diverse mean biomethane potentials per ha, considering the share of different cultivars. Districts with analogous characteristics can be more or less promising for the development of an artichoke-related biogas sector, depending on the cultivars commonly cultivated. For example, the amount of land cultivated with artichoke in D5 and D3 is the same (see Table 1). Nevertheless, the contribution from Madrigal and Tema in D3 creates a large gap in the biomethane potential, due to their higher $\mathrm{BMC}_{\mathrm{i}}$. Similarly, D2 has almost the same potential as D4 with a 15\% larger surface, but cultivated with a higher share of Spinoso sardo. The estimate here provided is strongly sensitive to variations of the surface cultivated with specific globe artichoke varieties, which depends on several agronomic, climatic, and economic factors.

In general, the artichoke agricultural system could benefit both as supplier of feedstock and as potential energy "prosumer" (producer and consumer). Likewise, biogas plants owners could rely on a local resource and substitute or integrate energy crops, at least during harvest periods. Furthermore, the replacement of silage corn with fresh or ensiled artichoke byproducts could be a significant option in the Mediterranean context, where summer energy crops are irrigated. Indeed, this substitution 
might reduce the irrigation water consumption for no-food crops. Furthermore, the residual biomass exploitation for biogas production would be an added value with respect to the optimization of nitrogen use. Since nitrogen fertilization is a standard agricultural practice for artichoke fresh market production, the residual biomass does not require the additional nitrogen supply that is, instead, a critical factor in energy crops balance.

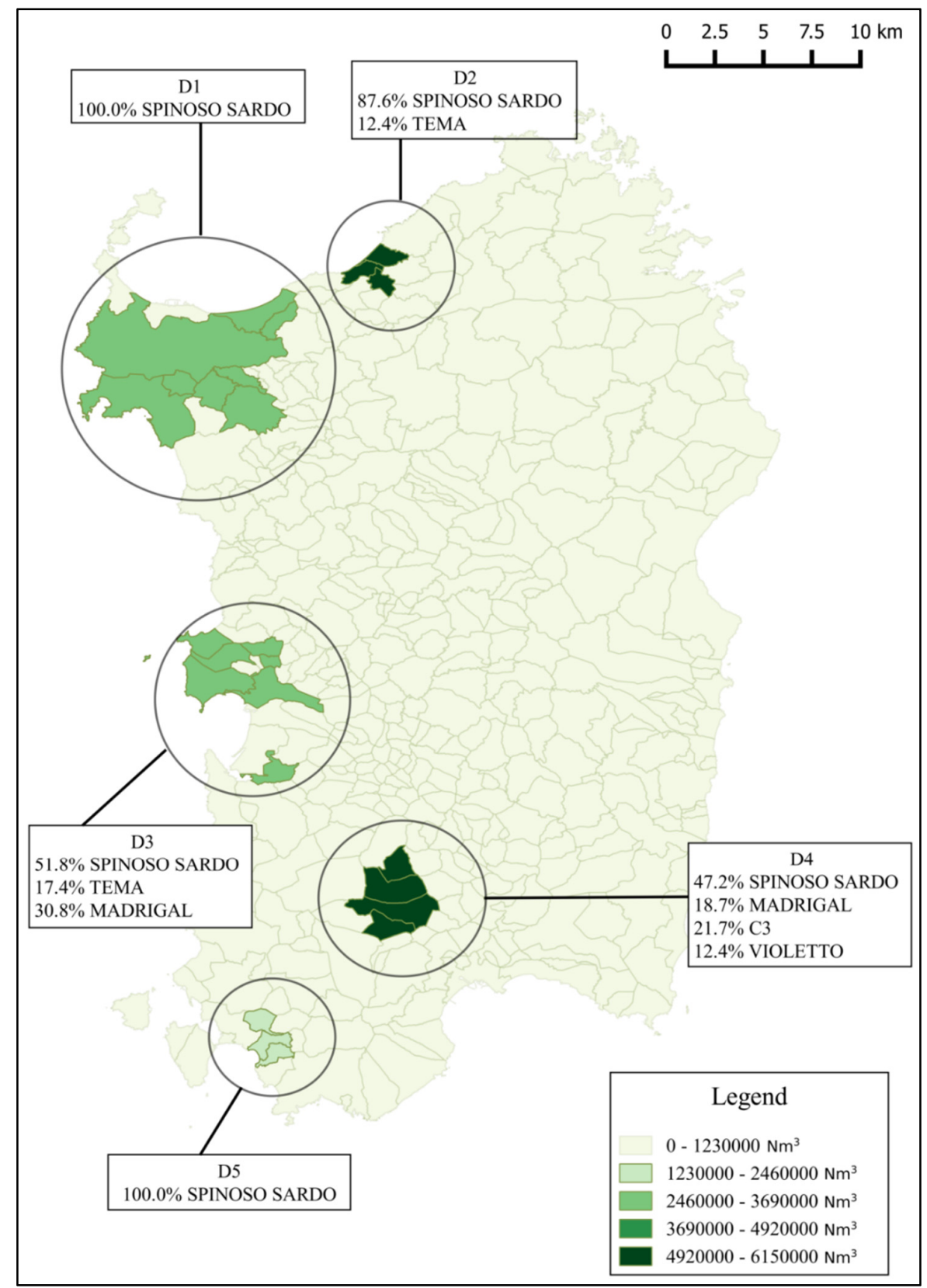

Figure 2. Map of biomethane per each district, year $2014\left(\mathrm{BMM}_{\mathrm{j}}\right.$ in $\mathrm{Nm}^{3}$ - average data under test condition $\left.\mathrm{A}\right)$.

\section{Conclusions}

The results of this research confirmed the potential double purpose for globe artichoke, with a promising application as feedstock for anaerobic digestion. Fresh residual biomass can be harvested and effectively utilized in operating biogas plants, allowing the integration of food and fuel production and a potential optimization of land use. There is some variability in the biomethane potential 
among the different cultivars. Madrigal and Tema are more suitable than Spinoso sardo or Violetto. This difference is due to both chemical characteristics of the residues and their yield per ha.

However, it must be underlined how farmers' choices related to varieties are determined by food market trends and agronomic features of cultivars. Another interesting aspect is that these differences among cultivars lead to dissimilar potentialities at the territorial level.

In general, our findings suggest that globe artichoke could have a major role in the Sardinian biogas sector, supplying up to the $60 \%$ of the total installed capacity. Regional policies and strategies should, therefore, encourage the sustainable use of globe artichoke byproducts in local bioenergy supply chains. Further research should assess the potential for the ensiling process of fresh artichoke byproducts in order to reduce its seasonality and optimize the substitution of energy crops use in existing AD plants.

Finally, a reliable regional assessment should carefully consider the sensitiveness to agronomic and economic variables, as residual biomass harvesting and transport costs. Further research should aim at assessing the economic impact of the use of these byproducts in the existing regional biogas sector, with a focus on energy crop substitution and supply chain optimization.

Acknowledgments: Authors would like to thank Paola Gamberini and Biological Care Ltd. for the technical advice and support.

Author Contributions: The manuscript has been read and approved by all named authors. Each co-author gave the same contribution to the reported research and writing the paper.

Conflicts of Interest: The authors declare no conflict of interest.

\section{References}

1. EurObserv'ER Biogas Barometer. 2014. Available online: http://www.eurobserv-er.org/biogas-barometer-2014/ (accessed on 10 September 2015).

2. Britz, W.; Delzeit, R. The impact of German biogas production on European and global agricultural markets, land use and the environment. Energy Policy 2013, 62, 1268-1275. [CrossRef]

3. Chinese, D.; Patrizio, P.; Nardin, G. Effects of changes in Italian bioenergy promotion schemes for agricultural biogas projects: Insights from a regional optimtization model. Energy Policy 2014, 75, 189-205. [CrossRef]

4. Carrosio, G. Energy production from biogas in the Italian countryside: Modernization vs. repeasantization. Biomass Bioenergy 2014, 70, 141-148. [CrossRef]

5. Harvey, M.; Pilgrim, S. The new competition for land: Food, energy, and climate change. Food Policy 2011, 36, S40-S51. [CrossRef]

6. Tilman, D.; Socolow, R.; Foley, J.A.; Hill, J.; Larson, E.; Lynd, L.; Pacala, S.; Reilly, J.; Searchinger, T.; Somerville, C.; et al. Beneficial biofuels-The food, energy, and environment trilemma. Science 2009, 325, 270-271. [CrossRef] [PubMed]

7. Murphy, R.; Woods, J.; Black, M.; McManus, M. Global developments in the competition for land from biofuels. Food Policy 2011, 36, S52-S61. [CrossRef]

8. Ciaian, P.; Kancs, D. Food, energy and environment: Is bioenergy the missing link? Food Policy 2011, 36, 571-580. [CrossRef]

9. Molari, G.; Milani, M.; Toscano, A.; Borin, M.; Taglioli, G.; Villani, G.; Zema, D.A. Energy characterisation of herbaceous biomasses irrigated with marginal waters. Biomass Bioenergy 2014, 70, 392-399. [CrossRef]

10. Styles, D.; Gibbons, J.; Williams, A.P.; Stichnothe, H.; Chadwick, D.R.; Healey, J.R. Cattle feed or bioenergy? Consequential life cycle assessment of biogas feedstock options on dairy farms. GCB Bioenergy 2014, 7, 1034-1049. [CrossRef]

11. Lijó, L.; González-García, S.; Bacenetti, J.; Negri, M.; Fiala, M.; Feijoo, G.; Moreira, M.T. Environmental assessment of farm-scaled anaerobic co-digestion for bioenergy production. Waste Manag. 2015, 41, 50-59. [CrossRef] [PubMed]

12. Huttunen, S.; Manninen, K.; Leskinen, P. Combining biogas LCA reviews with stakeholder interviews to analyse life cycle impacts at a practical level. J. Clean. Prod. 2014, 80, 5-16. [CrossRef]

13. Dressler, D.; Loewen, A.; Nelles, M. Life cycle assessment of the supply and use of bioenergy: Impact of regional factors on biogas production. Int. J. Life Cycle Assess. 2012, 17, 1104-1115. [CrossRef] 
14. Italian Ministry of Economic Development. Incentives for Electric Renewable Energy Sources apart from PV. 2012, pp. 1-65. Available online: http://www.gse.it/_layouts/GSE_Portal2011.Structures/GSEPortal2011_FileDownload. aspx?FileUrl=http://www.gse.it//it/Qualifiche\%20e\%20certificati//GSE_Documenti\%2fIncentiviDM\%2fNormativa \%2fDM_6_luglio_2012.pdf\&SiteUrl=http://www.gse.it//it/Qualifiche\%20e\%20certificati/ (accessed on 13 September 2015).

15. Jury, C.; Benetto, E.; Koster, D.; Schmitt, B.; Welfring, J. Life cycle assessment of biogas production by monofermentation of energy crops and injection into the natural gas grid. Biomass Bioenergy 2010, 34, 54-66. [CrossRef]

16. Börjesson, P.; Berglund, M. Environmental systems analysis of biogas systems-Part II: The environmental impact of replacing various reference systems. Biomass Bioenergy 2007, 31, 326-344. [CrossRef]

17. Schievano, A.; D’Imporzano, G.; Orzi, V.; Colombo, G.; Maggiore, T.; Adani, F. Biogas from dedicated energy crops in Northern Italy: electric energy generation costs. GCB Bioenergy 2015, 7, 899-908. [CrossRef]

18. Kosseva, M.R. Management and processing of food wastes. In Comprehensive Biotechnology; Elsevier: Philadelphia, PA, USA, 2011; Volume 1, pp. 557-593.

19. De Menna, F.; Vittuari, M.; Molari, G. Impact evaluation of integrated food-bioenergy systems: A comparative LCA of peach nectar. Biomass Bioenergy 2014, 73, 48-61. [CrossRef]

20. Bonari, E.; Jodice, R.; Masini, S. L'impresa Agroenergetica. Ruolo e Prospettive Nello Scenario "2 Volte 20 per il 2020"; Edizioni Tullis: Rome, Italy, 2009.

21. Cavicchi, B.; Bryden, J.M.; Vittuari, M. A comparison of bioenergy policies and institutional frameworks in the rural areas of Emilia Romagna and Norway. Energy Policy 2014, 67, 355-363. [CrossRef]

22. Cocco, D.; Deligios, P.; Ledda, L.; Sulas, L.; Virdis, A.; Carboni, G. LCA study of oleaginous bioenergy chains in a mediterranean environment. Energies 2014, 7, 6258-6281. [CrossRef]

23. Calabrò, P.S.; Greco, R.; Evangelou, A.; Komilis, D. Anaerobic digestion of tomato processing waste: Effect of alkaline pretreatment. J. Environ. Manag. 2015, 163, 49-52. [CrossRef] [PubMed]

24. Schievano, A.; D'Imporzano, G.; Adani, F. Substituting energy crops with organic wastes and agro-industrial residues for biogas production. J. Environ. Manag. 2009, 90, 2537-2541. [CrossRef] [PubMed]

25. Kryvoruchko, V.; Machmüller, A.; Bodiroza, V.; Amon, B.; Amon, T. Anaerobic digestion of by-products of sugar beet and starch potato processing. Biomass Bioenergy 2009, 33, 620-627. [CrossRef]

26. Lanuzza, F.; Mondello, F.; Tripodo, M.M. Pathways to Environmental Sustainability; Salomone, R., Saija, G., Eds.; Springer International Publishing: Cham, Switzerland, 2014.

27. FAOSTAT Artichoke, Production of Commodity in Selected Country, Italy. 2013. Available online: http:/ / faostat3.fao.org/ (accessed on 17 September 2015).

28. ISTAT Table C08-Area (ha) and Yield (quintals): Asparagus, Chard, Turnip Greens, Artichoke. Detail per Province-Year 2013. Available online: http:/ /agri.istat.it/jsp/dawinci.jsp?q=plC080000030000103200\&an=2013 $\& \mathrm{ig}=1 \& \mathrm{ct}=250 \& \mathrm{id}=15 \mathrm{~A}|18 \mathrm{~A}| 28 \mathrm{~A}$ (accessed on 17 September 2015).

29. Pandino, G.; Lombardo, S.; Mauromicale, G. Globe artichoke leaves and floral stems as a source of bioactive compounds. Ind. Crops Prod. 2013, 44, 44-49. [CrossRef]

30. Raccuia, S.A.; Melilli, M.G.; Calderaro, P.; Scandurra, S. Globe artichoke genetic variability for residual biomass production as renewable resources of energy in South Italy. Acta Hortic. 2013, 983, 129-132. [CrossRef]

31. Foti, S.; Mauromicale, G.; Raccuia, S.A.; Fallico, B.; Fanella, F. Possible alternative utilization of Cynara spp. I. Biomass, grain yield and chemical composition of grain. Ind. Crops Prod. 1999, 10, 219-228. [CrossRef]

32. Ierna, A.; Mauromicale, G. Cynara cardunculus L. genotypes as a crop for energy purposes in a Mediterranean environment. Biomass Bioenergy 2010, 34, 754-760. [CrossRef]

33. Ierna, A.; Mauro, R.P.; Mauromicale, G. Biomass, grain and energy yield in Cynara cardunculus L. as affected by fertilization, genotype and harvest time. Biomass Bioenergy 2012, 36, 404-410. [CrossRef]

34. Cravero, V.; Martin, E.; Crippa, I.; Anido, F.L.; García, S.M.; Cointry, E. Fresh biomass production and partitioning of aboveground growth in the three botanical varieties of Cynara cardunculus L. Ind. Crops Prod. 2012, 37, 253-258. [CrossRef]

35. Ledda, L.; Deligios, P.; Farci, R.; Sulas, L. Biomass supply for energetic purposes from some Cardueae species grown in Mediterranean farming systems. Ind. Crops Prod. 2013, 47, 218-226. [CrossRef]

36. Scano, E.A.; Murroni, S.; Orrù, A.; Triverio, A.; Maxia, C.; Fenu, D.; Cossu, A.; Atzori, D. Documento di Indirizzo Sulle Fonti Energetiche Rinnovabili in Sardegna. Studio Sulle Potenzialità Energetiche Delle 
Biomasse. 2013. Available online: http://www.regione.sardegna.it/documenti/1_461_20131216100125.pdf (accessed on 14 September 2015).

37. Zaghloul, R.A.; Estefanous, A.N.; Hanafy Ehsan, A.; El-Akshar, Y.S. Biogas production from Artichoke processing wastes by using semi- continuous feeding system. In Proceedings of the Tenth Microbiology Conference, Cairo, Egypt, 11-14 November 2000; pp. 279-294.

38. Ros, M.; Franke-Whittle, I.H.; Morales, A.B.; Insam, H.; Ayuso, M.; Pascual, J.A. Archaeal community dynamics and abiotic characteristics in a mesophilic anaerobic co-digestion process treating fruit and vegetable processing waste sludge with chopped fresh artichoke waste. Bioresour. Technol. 2013, 136, 1-7. [CrossRef] [PubMed]

39. Aymerich, E.; Esteban-Gutiérrez, M.; Sancho, L. Analysis of the stability of high-solids anaerobic digestion of agro-industrial waste and sewage sludge. Bioresour. Technol. 2013, 144, 107-114. [CrossRef] [PubMed]

40. Fabbri, A.; Serranti, S.; Bonifazi, G. Biochemical methane potential (BMP) of artichoke waste: the inoculum effect. Waste Manag. Res. 2014, 32, 207-214. [CrossRef] [PubMed]

41. Scano, E.A.; Asquer, C.; Pistis, A.; Ortu, L.; Demontis, V.; Cocco, D. Biogas from anaerobic digestion of fruit and vegetable wastes: Experimental results on pilot-scale and preliminary performance evaluation of a full-scale power plant. Energy Convers. Manag. 2014, 77, 22-30. [CrossRef]

42. Oliveira, I.; Gominho, J.; Diberardino, S.; Duarte, E. Characterization of Cynara cardunculus L. stalks and their suitability for biogas production. Ind. Crops Prod. 2012, 40, 318-323. [CrossRef]

43. Holmes, D.; Moody, P.; Dine, D. Research Methods for the Biosciences; Oxford University Press: New York, NY, USA, 2011.

44. Taherzadeh, M.J.; Karimi, K. Pretreatment of lignocellulosic wastes to improve ethanol and biogas production: A review. Int. J. Mol. Sci. 2008, 9, 1621-1651. [CrossRef] [PubMed]

45. Mahmoud, E.K.; Abd EL-Kader, N.K. How the nitrogen fertilization dose affects the biochemical composition and net mineralization of the artichoke residues. J. Soil Sci. Plant Nutr. 2012, 12, 23-31. [CrossRef]

46. Plöchl, M.; Hilse, A.; Heiermann, M.; Suarez Quinones, T.; Budde, J.; Prochnow, A. Application of hydrolytic enzymes for improving biogas feedstock fluidity. CIGR Eng. J. 2009, IX, 1-16.

47. Geng, A.; Zou, G.; Yan, X.; Wang, Q.; Zhang, J.; Liu, F.; Zhu, B.; Zhou, Z. Expression and characterization of a novel metagenome-derived cellulase Exo2b and its application to improve cellulase activity in Trichoderma reesei. Appl. Microbiol. Biotechnol. 2012, 96, 951-962. [CrossRef] [PubMed]

48. VDI. VDI 4630 Fermentation of Organic Materials-Characterization of the Substrate, Sampling, Collection of Material Data, Fermentation Tests; VDI-Gesellschaft Energie und Umwelt. 2014. Available online: http://www.vdi.eu/guidelines/vdi_4630-vergaerung_organischer_stoffe_substratcharakterisierung_probenahme_ stoffdatenerhebung_gaerversuche/ (accessed on 18 September 2015).

49. Müller, W.R.; Frommert, I.; Jörg, R. Standardized methods for anaerobic biodegradability testing. Rev. Environ. Sci. Biotechnol. 2004, 3, 141-158. [CrossRef]

50. Muntoni, M.; Pisanu, A.B.; Ledda, L. Carciofo in Sardegna. In Il Carciofo e il Cardo; ART Servizi Editoriali S.p.A.: Bologna, Italy, 2010; pp. 124-135.

51. Ledda, L.; Leoni, S. Con il traino del carciofo. Colt. Protette 2004, 12, $19-21$.

52. Poddighe, G.M. Personal Communication 2015; LAORE Sardegna (Unità organizzativa Produzioni vegetali Area 1): Valledoria, Sassari, Italy, 2015.

53. Ward, A.J.; Hobbs, P.J.; Holliman, P.J.; Jones, D.L. Optimisation of the anaerobic digestion of agricultural resources. Bioresour. Technol. 2008, 99, 7928-7940. [CrossRef] [PubMed]

54. Harikishan, S. Biogas processing and utilization as an energy source. In Anaerobic Biotechnology for Bioenergy Production; Wiley-Blackwell: Hoboken, NJ, USA; pp. 267-291.

55. Godin, B.; Mayer, F.; Agneessens, R.; Gerin, P.; Dardenne, P.; Delfosse, P.; Delcarte, J. Biochemical methane potential prediction of plant biomasses: Comparing chemical composition versus near infrared methods and linear versus non-linear models. Bioresour. Technol. 2014, 175, 382-390. [CrossRef] [PubMed]

56. Bruni, E.; Jensen, A.P.; Pedersen, E.S.; Angelidaki, I. Anaerobic digestion of maize focusing on variety, harvest time and pretreatment. Appl. Energy 2010, 87, 2212-2217. [CrossRef]

(C) 2016 by the authors; licensee MDPI, Basel, Switzerland. This article is an open access article distributed under the terms and conditions of the Creative Commons by Attribution (CC-BY) license (http://creativecommons.org/licenses/by/4.0/). 